\title{
Peran Orang Tua Dalam Pembelajaran Luring Di Masa Pandemi Covid-19 Terhadap Hasil Belajar Siswa Kelas II SD Negeri 01 Padang Laweh
}

\author{
Arum Susilowati ${ }^{1)}$ \\ Muhammad Subhan ${ }^{2)}$ \\ Raimon Efendi ${ }^{3}$ ) \\ 1) Fakultas Keguruan Dan Ilmu Pendidikan Universitas Dharmas Indonesia
}

arumsusilowati15@gmail.com

\begin{abstract}
ABSTRAK
Adanya pandemi covid-19 menyebabkan proses belajar mengajar harus dilaksanakan di rumah. Di SD Negeri 01 Padang Laweh memilih alternatif pembelajaran secara luring atau diluar jaringan dikarenakan kendala sulitnya jaringan internet, keberatan untuk membeli paket internet dan kebanyakan orang tua tidak memiliki handphone sehingga sekolah tidak bisa melaksanakan proses belajar mengajar secara daring atau online. Saat anak belajar di rumah secara luring peran orang tua sangat penting dan berpengaruh terhadap hasil belajar siswa. Penelitian ini bertujuan untuk mengetahui peran orang tua dalam pembelajaran luring terhadap hasil belajar siswa dan juga kesulitan yang dialami orang tua selama pembelajaran luring di SD Negeri 01 Padang Laweh Tahun Ajaran 2020/2021. Penelitian merupakan penelitian kualitatif dengan menggunakan pendekatan deksriptif. Karena proses pembelajaran luring dilaksanakan mulai bulan Juli sampai September, peneliti memilih jenis penelitian post ex faktor yaitu penelitian yang dilakukan disaat kejadian itu sudah terjadi. Subjek dalam penelitian ini yaitu kepala sekolah, guru kelas II, siswa kelas II dan orang tua siswa kelas II. Pengumpulan data diambil melalui wawancara, observasi dan dokumentasi. Hasil penelitian menunjukkan bahwa peran orang tua dalam pembelajaran luring di SD Negeri 01 Padang Laweh yaitu orang tua mengemban dua peran sekaligus pertama menjadi orang tua dan kedua menjadi guru di rumah walaupun tidak maksimal yang bisa membimbing dan mengawasi anak saat di rumah, menyampaikan materi pelajaran kepada anaknya saat belajar secara luring dengan menggunakan metode pembelajaran. Selain itu peran orang tua saat anak belajar luring adalah memberikan motivasi dan semangat untuk belajar, menyediakan sarana dan prasarana untuk anak belajar, menciptakan lingkungan belajar yang nyaman dan bisa mengarahkan anak pada bakat dan minat yang dimiliki oleh anak. Kesulitan yang dihadapi oleh orang tua saat pembelajaran luring ini dilaksanakan salah satunya adalah latar belakang pendidikan orang tua yang berbeda-beda. Hal ini dapat mempengaruhi kemampuan orang tua dalam mendidik dan membimbing anak saat belajar di rumah. Selain itu kesulitan yang dialami oleh orang tua adalah ketika anak tidak mau untuk belajar.
\end{abstract}

Kata Kunci : Peran orang tua, pembelajaran luring. 


\begin{abstract}
The Covid-19 pandemic has forced the teaching and learning process to be carried out at home. At SD Negeri 01 Padang Laweh, they choose alternative learning offline or outside the network due to the difficulty of the internet network, objections to buying internet packages and most parents do not have mobile phones so that schools cannot carry out the online or online teaching and learning process. When children study at home offline, the role of parents is very important and influences student learning outcomes. This study aims to determine the role of parents in offline learning on student learning outcomes and also the difficulties experienced by parents during offline learning at SD Negeri 01 Padang Laweh for the 2020/2021 Academic Year. This research is a qualitative research using a descriptive approach. Because the offline learning process was carried out from July to September, the researchers chose the type of post ex factor research, namely research conducted when the incident had occurred. The subjects in this study were the principal, class II teachers, class II students and parents of class II students. Data collection was taken through interviews, observation, documentation. The results show that the role of parents in offline learning at SD Negeri 01 Padang Laweh is that parents carry out two roles at once, first as parents and secondly as teachers at home, although not optimally able to guide and supervise children at home, convey subject matter to students. Their children while learning offline using learning methods. In addition, the role of parents when children study offline is to provide motivation and enthusiasm for learning, provide facilities and infrastructure for children to learn, create a comfortable learning environment and can direct children to their talents and interests. One of the difficulties faced by parents when offline learning is carried out is the different educational backgrounds of parents. This can affect the ability of parents to educate and guide their children while studying at home. In addition, the difficulty experienced by parents is when children do not want to learn.
\end{abstract}

Keywords : The role of parents, offline learning.

\title{
PENDAHULUAN
}

Anak adalah anugerah terindah dan harta yang tidak ternilai harganya, yang membutuhkan kasih sayang dan perlindungan dari kedua orang tuanya. Menurut pasal 1 ayat 2 Undang-Undang RI Nomor 23 Tahun 2002 tentang perlindungan anak, bahwa perlindungan anak adalah segala sesuatu untuk menjamin anak dan hak-haknya agar dapat hidup, tumbuh, berkembang, dan berpastipasi secara optimal sesuai dengan harkat dan martabat kemanusiaan serta mendapat perlindungan dari kekerasan dan diskriminasi. Allah SWT menciptakan anak yang dititipkan kepada kedua orang tuanya dengan dibekali kemampuan-kemampuan alamiah yang bisa diarahkan kedalam kebaikan atau sebaliknya. Menurut Patmonodewo (2003:123) dalam (Orang et al., (2016) orang tua adalah guru pertama bagi anak-anaknya. Apabila anak telah masuk sekolah, orang tua 
adalah mitra kerja guru bagi anaknya dan orang tua merupakan guru utama yang menggunakan segala kemampuan mereka, guna keuntungan mereka sendiri, anakanaknya, serta program yang dijalankan anak itu sendiri. Orang tua, anak dan program sekolah merupakan bagian dari suatu proses membentuk perkembangan anak. Tugas orang tualah untuk mendidik dan mengembangkan kemampuan-kemampuan tersebut kearah kebaikan dengan melatih anak sedari dini untuk melakukan kebaikan kesesama makhluk ciptaan Allah SWT dan peraturan-peraturan yang berlaku agar mampu hidup dan tumbuh besar menjadi manusia yang berbudi pekerti yang baik.

Upaya untuk meningkatkan kualitas (SDM) Sumber Daya Manusia salah satunya adalah melalui pendidikan. Berbicara tentang pendidikan anak, orang tua lah yang mengemban tanggung jawab terhadap pendidikan anak-anaknya. Pendidikan pertama seorang anak adalah di lingkungan keluarga. Di lingkungan keluarga anak mulai mengalami proses sosialisasi, mengenal dunia sekitar dan mengenal pola pergaulan yang berlaku di dalam kehidupan sehari-hari. Pendidikan selanjutnya diperoleh anak di lingkungan sekolah. Saat anak mulai memasuki lingkungan sekolah, anak akan menemukan hal-hal baru yang tidak ditemukannya saat berada di lingkungan keluarga. Cara orang tua dalam mendidik anak akan berpengaruh terhadap kemampuan anak saat belajar di sekolah.

Saat ini sekolah-sekolah yang ada di Indonesia bahkan dunia terpaksa ditutup dan diharuskan untuk melaksanakan pembelajaran dari rumah baik secara daring (dalam jaringan) maupun luring (luar jaringan). Dikarenakan wabah covid-19 yang menyerang di seluruh dunia termasuk negara kita. Virus ini menyerang melalui sistem pernapasan dan termasuk penyakit yang mudah menular kepada orang lain. Apalagi anak-anak sangat rentang untuk tertular virus ini. Di Indonesia sudah banyak korban meninggal akibat virus covid-19. Demi memutus rantai penyebaran virus covid-19 di SD Negeri 01 Padang Laweh terpaksa melaksanakan pembelajaran dari rumah secara luring (diluar jaringan). Kompetensi melaksanakan pembelajaran luring maupun daring dapat ditingkatkan melalui bimbingan dengan metode konsultasi pada guru (Malyana, 2020).

Adanya Pandemi covid-19 yang menyerang di Indonesia bahkan dunia mengakibatkan proses belajar mengajar harus dilaksanakan di rumah demi menghindari 
kerumunan dan agar tidak tertular virus covid-19. Di SD Negeri 01 Padang Laweh memilih melaksanakan proses belajar mengajar secara luring atau di luar jaringan. Pembelajaran luar jaringan/offline (luring) menggunakan metode kunjungan ke rumah atau home visit dan dengan media modul belajar mandiri dan lembar kerja, bahan ajar cetak, alat peraga dan media yang berada di sekitar lingkungan rumah. Dengan melakukan pembelajaran kunjungan ke rumah siswa dan tetap mengindahkan protokol kesehatan, maka pendidik tetap dapat menyampaikan materi pembelajaran. Home Visit atau Kunjungan Rumah merupakan salah satu kegiatan pendukung bimbingan yang dilakukan oleh guru sebagai upaya mengumpulkan dan melengkapi data atau informasi mengenai peserta didik, dengan cara melakukan kunjungan ke rumah peserta didik dengan harapan dapat membantu menyelesaikan masalah pembelajaran yang dihadapi oleh siswa (Suhendro, 2020). Proses pembelajaran secara luring ini berpedoman pada buku paket dan buku pegangan siswa. Proses pembelajaran luring ini jelas berbeda dengan proses pembelajaran yang dilaksanakan di sekolah langsung secara tatap muka. Di saat anak belajar secara langsung di sekolah guru memegang peranan penting dalam hasil belajar yang diperoleh siswa dan ketercapaian materi yang harus di kuasai siswa. Tetapi saat anak belajar dari rumah secara luring peranan agar hasil belajar siswa meningkat dan ketercapaian materi yang harus dikuasai siswa berada di tangan orang tua yang membimbing dan mengawasi anak dalam belajar. Peran orang tua sangat berpengaruh selama anak belajar dari rumah secara luring selama Pandemi covid-19.

Pembelajaran luring di SD Negeri 01 Padang Laweh dilaksanakan mulai bulan Juli sampai bulan September. Pembelajaran secara luring ini dipilih melihat kondisi orang tua yang tidak mempunyai smartphone untuk menunjang pembelajaran secara online, keberatan untuk membeli paket internet dan kendala sulitnya sinyal internet. Di SD Negeri 01 Padang Laweh pelaksanaan pembelajaran luring ini dilaksanakan dengan sistem penjemputan tugas ke sekolah seminggu sekali dan disepakati tugas diambil pada hari selasa. Hal ini mengharuskan orang tua meluangkan waktunya untuk pergi ke sekolah untuk mengambil tugas anaknya. Belum lagi jika orang tua setiap hari harus bekerja untuk membantu perekonomian keluarga, mau tidak mau di hari selasa harus libur bekerja demi mengambil tugas anaknya agar bisa mengikuti proses pembelajaran dengan baik. Kadang-kadang orang tua lupa untuk datang ke sekolah untuk mengambil 
tugas anaknya. Guru tidak mempunyai wadah untuk memberikan informasi mengingatkan bahwa besok harus mengambil tugas ke sekolah, tidak mungkin juga jika guru harus mendatangi langsung ke rumah masing-masing. Sering juga terjadi tugas yang dikerjakan tidak sesuai dengan tugas yang diberikan di sekolah.

Peran orang tua dalam membimbing pembelajaran yang dilaksanakan dari rumah berpengaruh bagi anak-anaknya. Adanya kendala yang dihadapi orang tua tidak membuat orang tua putus asa dalam mendampingi anak belajar, orang tua akan mencari solusi dari masalah yang dihadapinya dengan baik. Adanya pandemi covid-19 ini yang mengharuskan belajar dari rumah, pembelajaran dapat berjalan dengan baik dengan berpartisipasinya orang tua dalam membimbing anaknya belajar yang dilakukan di rumah (Handayani et al., 2020).

Menurut Valeza (2017) dalam (Cahyati \& Kusumah, (2020) peran orang tua dalam menentukan prestasi belajar siswa sangatlah besar. Peran orang tua awalnya hanya menyiapkan sarapan dan baju sekolah sebelum anak berangkat sekolah kini harus ditambah dengan peran untuk membimbing dan mengawasi anak saat belajar dari rumah. Di saat anak belajar dari rumah orang tua harus berperan sebagai guru walaupun tidak maksimal. Orang tua melaksanakan dua peran sekaligus pertama menjadi orang tua dan kedua menjadi guru di rumah. Menyediakan sarana dan prasarana kepada anak, memberikan semangat, motivasi, mengarahkan anak sesuai dengan bakat dan minat yang dimiliki oleh masing-masing anak (Khalimah, 2021). Orang tua menjadi sumber bertanya ketika anak mengalami kesulitan saat belajar. Sehingga orang tua harus bisa memahami materi-materi yang sedang dipelajari anak-anaknya. Belum lagi jika anak tidak mau untuk belajar apalagi siswa kelas rendah sukanya hanya untuk bermain. Hal ini menjadi tugas orang tua agar anaknya mau untuk belajar.

Orang tua harus ekstra sabar dalam membimbing anak-anaknya saat belajar dari rumah. Orang tua yang selalu membimbing dan memberikan perhatian kepada anaknya saat belajar dari rumah pasti membuat anak semangat untuk belajar dan hasil belajar yang diperoleh anak pastinya memuaskan. Berbeda dengan orang tua yang acuh dan tidak mau membimbing anaknya untuk belajar dan mengerjakan tugas. Dan tugas dikerjakan oleh orang tuanya dan anak dibiarkan main. Akibatnya nanti ketika proses 
pembelajaran diperbolehkan secara tatap muka, minat anak untuk belajar berkurang dan saat belajar dikelas anak menjadi malas untuk mengerjakan latihan yang diberikan (Cahyati \& Kusumah, 2020).

Setiap orang tua pasti menginginkan anaknya berhasil dalam belajar. Tugas untuk mencapai keberhasilan anak dalam belajar adalah tugas guru. Tapi dikarenakan pembelajaran yang dilaksanakan di rumah tugas untuk mencapai keberhasilan anak dalam belajar berada ditangan orang tuanya. Keberhasilan anak dalam belajar bisa dilihat dari hasil belajar yang diperoleh oleh anak dalam kurun waktu satu semester. Menurut Dimyanti dan Mudjiono (1999) dalam (Firmansyah, (2006) hasil belajar merupakan hal yang dipandang dari dua sisi yaitu sisi siswa dan sisi guru. Hasil belajar adalah kemampuan yang dimiliki setelah menerima pengalaman belajar.

Dalam hal ini peran orang tua adalah membimbing dan memberikan motivasi kepada anak, agar anak tetap bersemangat dalam melakukan kegiatan di rumah. Pada dasarnya anak memiliki motivasi untuk melakukan suatu hal, apabila ia mendapatkan sebuah dorongan dari orang-orang terdekat seperti orang tua (Yulianti, 2014) dalam (Islam et al., 2021). Peran orang tua saat membimbing dan mengawasi anak saat belajar memiliki andil yang besar terhadap hasil belajar yang diperoleh anak saat belajar dirumah. Peran orang tua dalam memberikan pemahaman kepada anaknya yang belum mengerti akan situasi pandemi covid-19 yang mengharuskan untuk berdiam diri di rumah agar tidak tertular dan menularkan wabah virus covid-19 dan orang tua dapat meningkatkan kelekatan hubungan dengan anaknya dan orang tua dapat melihat langsung perkembangan kemampuan anaknya dalam belajar (Cahyati \& Kusumah, 2020).

Tujuan penelitian ini adalah untuk mengetahui peran orang tua di saat pembelajaran secara luring terhadap hasil belajar yang diperoleh anak, baik itu dalam segi bagaimana orang tua membimbing anak, metode yang digunakan orang tua saat menyampaikan materi dan cara yang digunakan orang tua untuk memotivasi anak agar mau belajar dan mengerjakan tugas. 
Berdasarkan latar belakang, maka dapat ditarik rumusan masalah, Bagaimana peran orang tua membimbing anak saat belajar secara luring dan kesulitan yang dialami orang tua selama pembelajaran luring.

\section{METODE PENELITIAN}

Penelitian ini menggunakan metode penelitian kualitatif, yang menggunakan landasan teori sebagai panduan untuk memfokuskan penelitian serta menonjolkan proses dan makna yang terdapat dalam fenomena tersebut. Karena proses pembelajaran luring hanya dilaksanakan mulai bulan Juli sampai dengan bulan September peneliti memilih jenis penelitian ex post factor. Definisi penelitian ex post facto adalah sesudah fakta, yaitu penelitian yang dilakukan setelah suatu kejadian itu terjadi (El-Dairi \& House, 2019). Menurut Strauss dan Corbin dalam (Moha \& sudrajat, (2019) yang dimaksud dengan penelitian kualitatif adalah jenis penelitian yang menghasilkan penemuan-penemuan yang tidak dapat dicapai (diperoleh) dengan menggunakan prosedur-prosedur statistik atau cara-cara lain dari kualifikasi (pengukuran). Menurut Sugiyono (2007: 1) dalam (Prasanti, (2018), metode penelitian kualitatif merupakan suatu penelitian yang digunakan untuk meneliti pada objek yang alamiah dimana peneliti adalah sebagai instrumen kunci, teknik pengumpulan data dilakukan secara gabungan, analisis data bersifat induktif, dan hasil penelitian kualitatif lebih menekankan makna daripada generalisasi. Penelitian kualitatif Penelitian ini dilaksanakan pada Kelas II di SD Negeri 01 Padang Laweh. Waktu penelitian ini dilaksanakan pada semester dua tahun ajaran 2020/2021.

Data dan sumber data dalam penelitian ini yang peneliti ambil adalah sumber data primer dan sumber data sekunder. Sumber data primer dalam penelitian ini adalah siswa kelas II dan orang tua siswa kelas II dengan tujuan memperoleh data pokok. Sumber data sekunder yaitu kepala sekolah dan guru kelas II SD Negeri 01 Padang Laweh dengan tujuan sumber data ini agar bisa memperoleh data tambahan.

Instrumen yang digunakan peneliti dalam penelitiannya yaitu instrumen pokok dan instrumen penunjang. Instrumen pokok adalah manusia itu sendiri dan instrumen 
penunjang adalah pedoman wawancara berupa lembar wawancara, pedoman observasi berupa lembar observasi dan dokumentasi berupa kamera, alat perekam atau handphone.

Teknik pengumpulan data dalam penelitian ini yaitu melalui wawancara, observasi dan dokumentasi. Tujuannya agar penulis bisa memperoleh data-data yang diperlukan dalam penelitiannya. Peneliti memilih kriteria kepercayaan (creadbility) dalam penelitiannya. Kriteria kepercayaan berguna untuk memilah data secara akurat agar tingkat kepercayan dapat dicapai. Peneliti melakukan secara langsung dan mendetail berkenaan peran orang tua kelas 2 dalam pembelajaran luring di rumah. Dari data yang diperoleh dari wawancara, observasi dan dokumentasi sampai dirasa data-data yang diperlukan sudah cukup.

Teknik analisis data yaitu data reduction, data display dan conclusion drawing/verification. 1) Data Reduction (Reduksi Data) adalah data yang sudah diperoleh dari wawancara, observasi, dan dokumentasi. Selanjutnya masuk pada tahap reduksi data untuk memilah-milah data yang dibutuhkan, membuang data yang dirasa tidak perlukan dan memfokuskan terkait peran orang tua dalam pembelajaran luring terhadap hasil belajar siswa di masa pandemi covid-19 di kelas II SD Negeri 01 Padang Laweh. 2) Data Display (Penyajian Data) dalam penelitian kualitatif, penyajian data bisa dilakukan dalam bentuk uraian singkat, bagan, hubungan antar kategori, flowchart, dan sejenisnya. Melalui tahap penyajian data peneliti bisa memahami apa yang telah dipahaminya. Penyajian data dalam penelitian ini menjabarkan hasil penelitian dalam bentuk teks naratif, sehingga peneliti bisa menyajikan data hasil penelitiannya secara rinci dan sistematis. Data yang disajikan harus sesuai dengan penelitian peran orang tua dalam pembelajaran luring terhadap hasil belajar di masa pandemi covid-19 di kelas II SD Negeru 01 Padang Laweh. 3) Conclusion Drawing/Verification adalah tahap terakhir dalam analisis data yaitu verification atau penarikan kesimpulan. Peneliti melakukan penarikan kesimpulan dengan didasari bukti-bukti data yang konsisten saat peneliti ke sekolah yang diteliti untuk mengumpulkan data-data. Sehingga kesimpulan yang dibuat merupakan kesimpulan yang kreadibel. 


\section{HASIL DAN PEMBAHASAN}

Peran orang tua saat pembelajaran luring

Hasil penelitian yang peneliti lakukan di SD Negeri 01 Padang Laweh, dari hasil wawancara peran orang tua selama pembelajaran luring sangat penting dan berpengaruh terhadap hasil belajar anak selama proses pembelajaran dilaksanakan di rumah. Orang tua siswa kelas II sudah paham akan pentingnya peran yang diberikan selama pembelajaran dilaksanakan di rumah secara luring. Tugas orang tua selama pembelajaran luring adalah orang tua harus mengawasi dan membimbing anak saat belajar di rumah.

Pertama orang tua harus bisa mengemban dua peran sekaligus yang pertama peran sebagai orang tua dan yang kedua peran sebagai guru saat anak belajar dari rumah meskipun tidak maksimal seperti guru yang mengajar di sekolah. Sebagai guru di rumah saat anak belajar secara luring, orang tua harus bisa menyampaikan materi pelajaran kepada anak-anaknya. Kebanyakan orang tua menyampaikan materi pelajaran dengan metode ceramah sedangkan orang tua yang tidak mengerti dengan metode pembelajaran mereka sampaikan materi pelajaran kepada anak sebisanya saja. Beberapa orang tua juga ada yang tidak menyampaikan materi pelajaran ke anak-anaknya.

Kedua orang tua berperan sebagai guru di rumah saat pembelajaran luring. Orang tua juga bisa berperan sebagai fasilitator selama anak belajar dari rumah. Peran orang tua sebagai fasilitator adalah mencukupi semua kebutuhan anak selama belajar di rumah secara luring. Kebutuhan anak saat belajar secara luring adalah anak membutuhkan lingkungan belajar yang nyaman. Cara yang orang tua lakukan untuk menciptakan lingkungan belajar yang nyaman adalah dengan televisi dimatikan saat anak belajar dan adiknya di jauhkan dari kakaknya selama belajar agar tidak menggangu.

Ketiga orang tua juga bisa berperan sebagai motivator untuk anaknya selama belajar di rumah. Orang tua bisa memberikan motivasi dan semangat agar anak semangat untuk belajar dan mengerjakan tugas-tugas yang diberikan. Hal ini sudah dilakukan oleh orang tua siswa kelas II selama pembelajaran luring dilaksanakan. Selain 
memberikan semangat dan motivasi orang tua juga bisa memberikan reward atau penghargaan kepada anak agar semangat anak belajar semakin tinggi.

Jadi selama pembelajaran luring di rumah peran orang tua menjadi bertambah. Peran orang tua yang awalnya hanya menyiapkan baju sekolah dan sarapan sebelum berangkat sekolah. Kini harus di tambah nek peran sebagai guru yang mengawasi dan membimbing anak belajar. Tidak hanya membimbing dan mengawasi belajar orang tua juga harus bisa menyampaikan materi pelajaran kepada anak-anaknya. Selain itu peran orang tua selama pembelajaran luring adalah orang tua berperan sebagai fasilitator dan orang tua berperan sebagai motivator.

\section{Kesulitan yang dialami Orang Tua Saat Pembelajaran Luring}

Kesulitan yang dihadapi orang tua selama pembelajaran luring di SD Negeri 01 Padang Laweh Tahun Ajaran 2020/2021. Hasil penelitian dari proses wawancara kesulitan yang dialami orang tua selama pembelajaran luring hampir semua memiliki kesulitan yang sama. Pertama orang tua kesulitan dalam membimbing anak untuk mengerjakan tugas yang diberikan. Sehingga orang tua harus mempelajari materi yang bukan bidangnya, karena tidak semua orang tua dari siswa kelas II memiliki latar belakang pendidikan yang tinggi. Bagi orang tua yang memiliki latar belakang pendidikan yang rendah, jika ada tugas anak dan orang tua tidak mengerti biasanya orang tua bertanya kepada tetangga sekitar rumah.

Kedua kesulitan yang orang tua alami adalah mengatur waktu belajar anak. Belum lagi jika orang tua setiap harinya bekerja hal ini menjadi tantangan bagi orang tua untuk bijak dalam membagi waktu untuk anaknya. Dari hasil wawancara kebanyakan waktu belajar anak adalah di malam hari. Bagi orang tua yang tidak bekerja atau hanya sebagai ibu rumah tangga. Setelah pekerjaan rumah selesai orang tua langsung membimbing anak untuk belajar.

Ketiga kesulitan lainnya yang orang tua alami saat pembelajaran luring adalah jika anak tidak mau untuk belajar. Apalagi siswa kelas rendah sukanya hanya untuk bermain. Karena keasikan bermain anak menjadi kelelahan dan akhirnya tidak mau untuk belajar. 
Dari hasil wawancara ada salah satu siswa yang sama sekali tidak mau untuk belajar bahkan tugas yang diberikan dikerjakan oleh orang tuanya. Setiap diingatkan untuk belajar anak menolak dan menangis karena tidak mau belajar. Tetapi juga ada siswa yang tanpa diingatkan untuk belajar anak tersebut belajar dengan keinginan dirinya sendiri.

Jadi selama pembelajaran luring berlangsung dengan rumah orang tua mengalami beberapa kesulitan saat membimbing dan mengawasi anak dalam belajar. Kesulitankesulitan itu adalah latar belakang pendidikan orang tua yang berbeda-beda sehingga orang tua yang berpendidikan rendah kesulitan apabila ada tugas yang begitu sulit. Kesulitan lainnya adalah mengatur waktu belajar anak selama pembelajaran luring dan apabila anak tidak mau untuk belajar karena keasikan bermain sehingga lupa untuk belajar.

\section{KESIMPULAN}

Berdasarkan hasil penelitian dapat disimpulkan bahwa peran orang tua dalam pembelajaran luring di SD Negeri 01 Padang Laweh yaitu orang tua mengemban dua peran sekaligus pertama menjadi orang tua dan kedua menjadi guru di rumah walaupun tidak maksimal yang bisa membimbing dan mengawasi anak saat di rumah, menyampaikan materi pelajaran kepada anaknya saat belajar secara luring dengan menggunakan metode pembelajaran. Selain itu peran orang tua saat anak belajar luring adalah memberikan motivasi dan semangat untuk belajar, menyediakan sarana dan prasarana untuk anak belajar, menciptakan lingkungan belajar yang nyaman dan bisa mengarahkan anak pada bakat dan minat yang dimiliki oleh anak.

Kesulitan yang dihadapi oleh orang tua saat pembelajaran luring ini dilaksanakan salah satunya adalah latar belakang pendidikan orang tua yang berbeda-beda. Hal ini dapat mempengaruhi kemampuan orang tua dalam mendidik dan membimbing anak saat belajar di rumah. Selain itu kesulitan yang dialami oleh orang tua adalah ketika anak tidak mau untuk belajar. Kemauan untuk belajar dipengaruhi oleh beberapa faktor yaitu karena anak keasikan bermain dan akhirnya anak kecapekan dan menggantuk 
akhirnya tidak mau untuk belajar. Selain itu faktor kebanyakan bermain handphone juga dapat berpengaruh terhadap kemauan anak dalam belajar.

\section{SARAN}

Berdasarkan hasil penelitian, pembahasan dan kesimpulan di atas peneliti ingin menyampaikan beberapa saran yang akan disampaikan, yaitu : Orang tua diharapkan bisa membimbing dan mengawasi anak saat belajar, memberikan lingkungan belajar yang nyaman, selalu mendampingi anak saat belajar dan memberikan semangat dan motivasi kepada anak-anaknya. sesuai kebutuhan anak serta menyediakan fasilitas belajar yang cukup sehingga anak nyaman saat belajar dari rumah secara luring. Guru kelas diharapkan bisa memantau dan mengontrol proses pembelajaran secara luring serta menjalin komunikasi dan kerja sama yang baik dengan orang tua sehingga tujuan pembelajaran bisa tercapai meskipun proses pembelajaran dilaksanakan secara luring dirumah. Siswa diharapkan memiliki semangat belajar yang tinggi sehingga bisa melaksanakan pembelajaran secara luring dengan baik dan agar bisa memperoleh hasil belajar yang memuaskan.

\section{DAFTAR RUJUKAN}

Cahyati, N., \& Kusumah, R. (2020). Peran Orang Tua Dalam Menerapkan Pembelajaran Di Rumah Saat Pandemi Covid 19. Jurnal Golden Age, 4(01), 4-6. https://doi.org/10.29408/jga.v4i01.2203

El-Dairi, M., \& House, R. J. (2019). penelitian EX POST FACTO. In Handbook of Pediatric Retinal OCT and the Eye-Brain Connection (pp. 285-287). https://doi.org/10.1016/B978-0-323-60984-5.00062-7

Firmansyah, A. (2006). Meningkatkan Hasil Belajar Siswa Melalui Strategi Pembelajaran Berbasis Masalah Pada Mata Pelajaran IPS di Kelas V SDN 2 Limbo Makmur Kecamatan Bumi Raya. 3(1).

Handayani, T. R. I., Guru, P., Ibtidaiyah, M., Tarbiyah, F., \& Ilmu, D. A. N. (2020). PADA PEMBELAJARAN DARING DI DESA NGRAPAH SKRIPSI.

Islam, P., Usia, A., \& Gresik, U. M. (2021). Jurnal Obsesi : Jurnal Pendidikan Anak Usia Dini Peran Orang Tua dalam Mendukung Kegiatan Pembelajaran di Rumah pada Masa Pandemi Abstrak. 5(1), 549-558. https://doi.org/10.31004/obsesi.v5i1.630 
Khalimah, N. (2021). Peran orang tua dalam pembelajaran daring di mi darul ulum pedurungan kota semarang tahun pelajaran 2020/2021 skripsi.

Malyana, A. (2020). Pelaksanaan Pembelajaran Daring dan Luring Dengan Metode Bimbingan Berkelanjutan Pada Guru Sekolah Dasar Di Teluk Betung Utara Bandar Lampung. Jurnal Ilmiah Pendidikan Dasar Indonesia, 2(1), 67-76.

Moha, I., \& sudrajat, D. (2019). Resume Ragam Penelitian Kualitatif. https://doi.org/10.31227/osf.io/wtncz

Orang, P., Dalam, T. U. A., Perkembangan, M., Dini, U., Desa, D. I., Pinang, A. I. R., \& Simeulue, K. (2016). peran orang tua dalam meningkatkan perkembangan anak. $1,22-30$.

Prasanti, D. (2018). Penggunaan Media Komunikasi Bagi Remaja Perempuan Dalam Pencarian Informasi Kesehatan. LONTAR: Jurnal Ilmu Komunikasi, 6(1), 13-21. https://doi.org/10.30656/lontar.v6i1.645

Suhendro, E. (2020). Strategi Pembelajaran Pendidikan Anak Usia Dini di Masa Pandemi Covid-19. Golden Age: Jurnal Ilmiah Tumbuh Kembang Anak Usia Dini, 5(3), 133-140. https://doi.org/10.14421/jga.2020.53-05 